RAI - Revista de Administração e Inovação

ISSN: $1809-2039$

DOI: $10.5773 /$ rai.v11i 2.1292

Organização: Comitê Científico Interinstitucional

Editor Científico: Milton de Abreu Campanario

Avaliação: Double Blind Review pelo SEER/OJS

\title{
FACTORS FOR SELECTING PARTNERS IN INNOVATION PROJECTS - EVIDENCES FROM ALLIANCES IN THE BRAZILIAN PETROCHEMICAL LEADER
}

\author{
Marcos Paixão Garcez \\ Doutor em Administração pela Universidade de São Paulo - USP \\ Professor da Universidade Nove de Julho - UNINOVE \\ mpgarcez@uninove.br (Brasil)
}

\section{Roberto Sbragia}

Doutor em Administração pela Universidade de São Paulo - USP

Professor da Faculdade de Economia, Administração e Contabilidade da Universidade de São Paulo

- FEA/USP

rsbragia@usp.br (Brasil)

\section{Isak Kruglianskas}

Doutor em Administração pela Universidade de São Paulo - USP

Professor da Faculdade de Economia, Administração e Contabilidade da Universidade de São Paulo - FEA/USP

ikruglia@usp.br (Brasil)

\begin{abstract}
Due to the limitation of resources, the need to foster the developments and the lack of some competencies internally, companies are forced to cooperate with external agents, like other companies and universities, as suggested by the Open Innovation paradigm. Although there are lots of studies dealing with partner selection factors in alliances in the firm level, few studies are devoted to understand the specific demands of the task, in the project level, considered it the theoretical gap to be addressed in this study. The paper analyzes the partner selection factors in bilateral alliances projects, accordingly to the type of the partner and the type of innovation project. The data come from the case study in one Brazilian petrochemical company, analyzing in-depth 20 alliances projects with different partners - competitors, customers, suppliers, universities; and embodying different innovativeness degree - incremental innovation, platforms, breakthrough and basic science. Founded on the resources based view background, it was possible to identify the more prevalent selecting factors and alliances characteristics depending on the partner type and project type. The theoretical background jointly with the qualitative evidences enabled the building of theoretical propositions to be tested in future quantitative researches.
\end{abstract}

Key words: Innovation management; Technological alliances; Partner selection. 


\section{INTRODUCTION}

The strategic alliances started its rapid growth as one strategic alternative since the 1990's, widening its scope and coexistence with other organizational forms. Companies nowadays are required to build more extensively external cooperation agreements with other companies, universities and external agents, aiming for: (i) sharing investments and risks; (ii) accelerating project developments, and (iii) accessing resources and competences not available internally, as suggested by the Open Innovation paradigm. It is practically impossible to one company to maintain its competitive advantage without the adoption of external cooperation activities (Jonash \& Sommerlatte, 1999). The new paradigm conciliates internal and external efforts, as suggested by the Open Innovation model which emphasizes the systematic collaboration among involved parties (Chesbrough, 2003).

Although the existence of rich literature generated after the intensive growth of alliances as one important strategic option since the two last decades, only few studies deal with one crucial step of the process, the partner selection. Moreover, few studies consider a detailed breakdown structure regarding different typologies of partners and they only investigate the phenomena through the firm level, instead of the project level perspective. These aspects are considered the main theoretical gaps to be filled in the present study.

This paper aims to analyze the partner selection stage in non-equity bilateral alliances projects, under the point of view of the parent company, taking into account some selection factors, such as the kind of competencies searched, the type of the partner and the type of innovation project carried out., at the firm level perspective. It also highlights the convergence between alliances' portfolio management and the knowledge's access or creation. In fact, the companies need to deal with one conflict in the day-by-day management - to conciliate the efforts in the short-term, that guarantee its immediate survival, with the ones in the long-term, that enable the own company's sustainability over the time. The portfolio management theory sheds light to this controversial theme, suggesting the building of balanced portfolios of projects, applied to alliances' portfolio management. Founded in the resource based view and knowledge based view streams and taking into account the necessary knowledge for carrying out the different nature of projects - base or new knowledge, the study tries to identify empirical evidences that could differentiate the partner selection factors depending on the partner type and project nature groups, allowing the building of theoretical propositions discriminating the groups in comparison, which could be validated in future studies.

The present discussion can bring contributions and reflections on this relevant subject, in order to establish basic relationships that could help the selection of partners in alliances. Besides this 
introduction, a brief literature review is provided, covering aspects from innovation management to partner's selection in R\&D cooperation. Then, the alliances episodes are discussed, followed by analyses and useful interpretation. The theoretical propositions emerged from the cases grouping are then presented. Finally, some conclusions are derived, in order to stimulate and direct future studies on this subject.

\section{LITERATURE REVIEW}

\subsection{Innovation management}

The innovation management is considered vital for the sustainability of companies, since the companies started to find new approaches for reaching added value in the value chain, besides costs and flexibility (Kumpe \& Bolwjin, 1994; Jonash \& Sommerlatte, 1999), and its comprehension as one crucial management capability evolved so rapdily in the last 20 years (O'Reilly \& Tushman, 2007). According to the pioneer study of Clark and Fujimoto (1991), developing better products faster and more efficiently than the competitors is fundamental for the companies in the new competitive arena, bringing significant benefits in terms of costs, quality, customer satisfaction and competitive advantages. Best performers in this new environment show one adequate adjustment of the strategic objectives, by structuring and conciliating their Research \& Development (R\&D) portfolio up to an optimal point - fitted to the goals of launching new products and services in one systematic way, and using efficiently the competences and resources available, both internally and externally. Their performance also depends on how well the technological players take part of the development of products and services, contributing to a long term orientation and providing new critical capabilities. Besides that, the learning of the innovation process accelerates the time to market, fulfilling the market requisites and product specifications, without sacrifice the quality aspects (Schilling \& Hill, 1998). Although it makes sense, this task can be considered very critical, since companies frequently face ambiguities in their R\&D choices. At the same time that companies are forced to provide solutions for the current customers, introducing products and services - from incremental or platform innovations nature - and generating cash flows in the short-term, complying in this way to the shareholders expectations, they also need to focus on radical innovations in the medium/long terms, in order to obtain diversification of products and markets, mitigating the risks of a turbulent environment and making it possible to achieve stakeholders satisfaction and sustainability. Unfortunately, although radical innovations in general show better potential cash returns, they possess longer maturation terms,

Revista de Administração e Inovação, São Paulo, v. 11, n.2, p. 241-272, abr./jun. 2014. 
higher investments and higher uncertainty levels compared to the incremental or platform innovations (Tritle, Scriven \& Fusfeld, 2000). One recent example to illustrate this ambiguity can be credited to Pfizer, which has accumulated negative financial results for several years before achieving the impressive results derived from the success of new drugs introduction, as Viagra, Celebra and Lípitor, justifying completely the previous investments. In the 1990's, after restructuring the company and concentrating in two main activities: (i) the research and development of innovative human drugs $\mathrm{R} \& \mathrm{D}$, and (ii) animal health products, the CEO William C. Steere Jr. starts one strong reformulation in the company's image. Fifteen activities' areas were closed to concentrate in these two strategic businesses. In 1995 Pfizer acquires the animal division of Smithkline Beecham, the biggest acquisition in the Pfizer's history. In the final of the 1980's and beginning of the 1990's, when the giants of the pharmaceutical industry were entering in mergers' strategy, Pfizer ignored this strategy and invested billion of dollars in new drugs R\&D and expanding the sales team, what resulted in profit reduction and generated the financial analysts' skepticism. Pfizer has concentrated in the drugs developments that could represent significant medical advances, with the vision that they should be the first or better in their categories (http://www.pfizer.com.br). The Pfizer case highlights the importance for companies to manage simultaneously diverse categories of projects, creating one balanced and diversified portfolio, in order to obtain risks mitigation and profits maximization, and also to conciliate short and long term requisites.

\subsection{Portfolio management}

One important part of Innovation Management is Portfolio Management. It can be defined as one dynamic management process, where an active list of projects is constantly updated and reviewed (Cooper et al, 1997). Portfolio management encompasses some activities like: (i) new projects are evaluated, selected and prioritized; (ii) existent projects are accelerated, killed or put in "hold"; (iii) resources are allocated and reallocated to the active projects. The objectives of the Portfolio Management are: (i) establish the linkage of the projects within the business strategy, in order to maintain the business competitiveness; (ii) assure that only the best ideas could be transformed in projects, in order to maintain focus; (iii) manage the projects by means of balanced projects' families or programs; (iv) risks minimization and potential returns maximization; (v) efficient resources allocation, and finally (vi) one priority communication tool inside the company (Cooper et al, 1997). The main difficulties to manage the portfolio of projects, accordingly to Cooper et al. (1997) are: (i) high level of uncertainty, as it deals with future events, not precisely predictable, mainly in turbulent

Revista de Administração e Inovação, São Paulo, v. 11, n.2, p. 241-272, abr./jun. 2014. 
environments; (ii) huge necessity of information caused by the dynamic nature of the process; (iii) lack of strategic alignment or strategic importance of some projects; (iv) competing projects situated in different stages and carrying on different information levels; (v) shared decision making process, and finally, and (vi) lack of resources impose competition among the projects. Regarding the existent methodologies for Portfolio Management, there are different techniques that help the project evaluation, such as Financial, Scoring models, Bubble Diagrams and Strategic Buckets (Cooper et al, 1997).

Some questions arise immediately from this complex process. On one hand, the value maximization goal does not guarantee the strategic balance, e.g, lots of short term-short risk projects, concentrated in very few markets. On the other hand, one portfolio with accurate strategic orientation can sacrifice the short term financial profits. The conclusion is that traditional financial evaluations may not take into account strategic alignment and portfolio balancing. Thus, it is desirable to conciliate financial evaluation with other techniques, such as strategic buckets methodology and balanced allocation of resources (Cooper et al,, 2000).

\subsection{The technological strategy and its relation with the innovation portfolio}

According to Griffin and Page (1997), companies can elect proactive technology strategies prospector (equivalent to leader) or analyzer (equivalent to fast follower), or defensive technology strategies - defender (equivalent to follower) or reactor (equivalent to laggard). That choice depends on available competences, capabilities and resources. As per the authors, innovation leaders usually have more proactive strategies, and are more susceptible to adopt emergent and radical technologies, while reactors will adopt new technologies only when they are completely proven, at one mature stage, diffused and consolidated. They have carried out one research with 78 American companies from different sectors, analyzing the convergence among the innovation strategic posture and the deployment of resources in different kinds of projects, divided in the level of innovativeness power, by the following typology: new to the world (high product and market innovation), new to the company (high product innovation and low market innovation), add to existing lines (average product and market innovation), improvements (average product innovation and low market innovation), repositionings (low product innovation and average market innovation) and finally cost reduction projects (low product and market innovations). Then, they verified the resources allocation in those different project strategies portfolio, depending on the innovation strategy the companies were pursuing at that moment, like prospector, analyzer, defender or reactive innovation strategy. The

Revista de Administração e Inovação, São Paulo, v. 11, n.2, p. 241-272, abr./jun. 2014. 
results evidentiated the prospectors had in their innovation portfolio one significant amount of "new to the world" projects compared to the less proactive companies. And on the other hand, the analyzers, defenders and reactors companies had larger amount of incremental innovation projects compared to the prospectors. Thus, it is possible to conclude that the more defensive the innovation strategy is, more aversion to the risk will be present in the company. This fact is easily understood if we compare diverse characteristics of R\&D types, accordingly to Roussel, Saad and Bohliw (1992): in the incremental projects, the technical success probability is high (from 40 to $80 \%$ ), the time for completion is short, the competive potential is moderated but necessary and the longevity of competitive advantage is short and easily copied by the competitors. The radical projects show moderate technical success probability in the first stages (from 20 to 40\%), average time for completion, high competitive potential, long and patentable competitive advantage. Finally, in the science projects, the technical success probability is very difficult to evaluate in the first stages, the time for completion and the competitive potential are high, and the longevity of the competitive advantage acquired is generally long and patentable. In short, according to the theory, Innovation Management, and more specifically, Portfolio Management, should be one strategic and balanced oriented, in order to be effective, and it is also a complex and structured activity.

\subsection{Organizational dynamic ambidexterity and the exploration-exploitation learning capabilities}

Since Schumpeter's studies, in 1940's, much has been discussed about the need for renovation in companies. After many studies done, it is known that companies can make new products based on the internal existent competencies or through new competences that should be embedded. This dichotomic idea leads to the definition of exploitation, the former case, and exploration, the last (Daneels, 2002), following the terms created by March (1991). Thus, a challenge for companies can be identified - how to conciliate these two approaches, since both are necessary to the company's survival? Firms that are able to manage diferent uses of competences, exploitative and explorative, are called ambidextrous organizations. To achieve this status, these firms need to balance between activities that contribute to exploration of new knowledge or capabilities, and activities that contribute to exploitation of the existing knowledge or capability base of the firm. One strategic renewal theory should recognize that in order to a firm maintain the adaptability to the changing environment, it is required the joint use of competencies: both the existent internally (exploitative), added to new competencies for the firm (explorative). March (1991) argues that there are second order competences,

Revista de Administração e Inovação, São Paulo, v. 11, n.2, p. 241-272, abr./jun. 2014. 
or, in other words, explorative learning competences, that allow a firm to identify, explore and embed new technological or market-related competences, leading to a renovation on competences' portfolio. The presence of a second order competence would mitigate the risk of historical dependencies, or in other words, the estagnation in past consolidated competencies, that could block the orientation to new products and markets, obstructing the renovation (Daneels, 2002). In that way, it is crucial searching for new competences through explorative learning, joining with the exploitative competences available internally and thus making it possible to one firm to become one ambidextrous organization. Danneels (2002) has achieved empirical support for that reasoning, studying multiple cases of five Business to Business (B2B) companies acting in one high tech sector, varying the age, size and diversification degree. He has verified the relationship between companies' product innovation dynamics and the missing firm competences for each development evolutionary stage. So, using two dimensions, market (or customers) and technology, Danneels (2002) positioned the nature of needed competences, considering the availability of competences, existing in the firm or new to the firm. So, when in both dimensions the competences exist in the firm, we classify the situation as pure exploitation. Inversely, when the competences searched are new to the firm, the situation can be classified as pure exploration. And in the mid-term, when the tecnhological competence is available in the firm but lack the market competence, it is named leveraging technological competence. On the order hand, existing market competences within the firm and lacking the technological competences, the classification is leveraging market competence. Danneels (2002) also has discussed the specific projects characteristics depending on these nature of the innovation, pure exploitation, pure exploration, leveraging market competence and leveraging technological competence. Thus, to balance between the exploration and exploitation, it would be interesting to mantain a set of organizational activities, each of which contributes to a particular type of corporate renewal in the exploration-exploitation continuum (Burgelman \& Sayles, 1986; Keil, 2002).

\subsection{Corporate venturing strategies - the familiarity matrix}

During the 50's and 60's, many North American companies had initiated an intense process of diversification, mainly unrelated, motivated by the availability of capital and the strong antitrust regulation, and reached its apex in the end of the 60's and resulting in the sprouting of giant corporative conglomerates. In the 70's, after a history of unsuccessful diversifications and divestments, research has been focused on the understanding of the new businesses characteristics, being the precursor, Rumelt's (1974) pioneering study. Rumelt (1982) extended the universe of research of its

Revista de Administração e Inovação, São Paulo, v. 11, n.2, p. 241-272, abr./jun. 2014. 
original work, and studying several companies between 1974 and 1982, demonstrated that the related diversification presented better results than the unrelated one, which was confirmed in diverse subsequent researches. The high degree of failure of the diversifications has triggered the trend towards the return to the specialization in the beginning of the 90's, as showed by the studies of Berger and Ofek (1995) and Liebeskind and Opler (1993). Confirming these findings, Hunger and Wheelen (1995) supported that, as a generic rule it is recommendable, to minimize the risks, to prioritize the growth in the same business or industry until its attractiveness is depleted, however, taking into account that long term strategic factors can indicate a need of diversification. However, there was a lack of a prescriptive model dealing with the unrelated diversification - very important many times for reaching the strategic and long term goals- the one that could describe the best conditions necessary to adopt and optimize the results of these growth strategies. It was contemplated in the Roberts and Berry (1985) model, which provides the optimum situations for selecting the growth strategies, according to the degree of existing newness and familiarity with technologies and markets, and also depending on the selection factors, such as the level of available resources, the abilities and knowledge available in the technology and market dimensions, financial returns, involved risks, strategic fit, degree of diversification and corporate involvement of the parent company. They based on the researches of Rumelt (1982) and Peters (1980), referring to the lower degree of involved risk in related diversification, and on the reasoning of different degrees of involvement of the corporation with the new business, and formulated diverse hypotheses, which had been checked in a field research trying to identify the responsible factors for the success or failure of the ventures. This research has deeply studied a highly diversified American company, analyzing the performance of 14 new businesses (6 internal developments, 6 acquisitions and 2 venture capital initiatives), generating a model called "familiarity matrix". According to this matrix, there are optimal strategies situations to be elected depending on the level of familiarity attained at that moment, in two dimensions, technology and market. Maula (2001) argues that the researches of Roberts and Berry (1985) were concentrated in building a more systematic vision of the various alternatives used in the development of new businesses. Accordingly to Dussauge, Hart and Ramanantsoa (1992), the advantage of the Roberts and Berry's matrix is that it considers the position of the companies with respect to these technologies, in terms of its familiarity. The major contribution of this model resides in the possibility of choosing the entry strategy better indicated for the minimizing of the risks and the increase of the success probability, mainly in situations of diversification, in which the absence of familiarity with the new technology and/or the new market was considered a restrictive element of the success in the previous approach by Rumelt (1982). Taking as reference the typology described by Clark and Wheelright 
(1993) for the types of project - classified in basic R\&D projects (or advanced), breakthrough projects (radical innovation), platform projects (significant improvements with new architecture and new generation of products), and finally the derivative projects (only incremental improvements for specific needs of groups of customers), and comparing them with the type of innovation, its complexity and the familiarity in each type, it seems logical to assume that they could also be located in the Roberts and Berry familiarity matrix, adapted for the possible non-equity alliance types. So, by joining the findings of Roberts and Berry (1985), regarding Corporate venturing strategies, and the March (1991) and Danneels (2002) conclusions about the exploitative-explorative knowledge, we designed one pictorial matrix, as shown in the Fig. 1, for better illustrate the development possibilities and to provide more intuitive comprehension of the theoretical propositions that will be further developed.

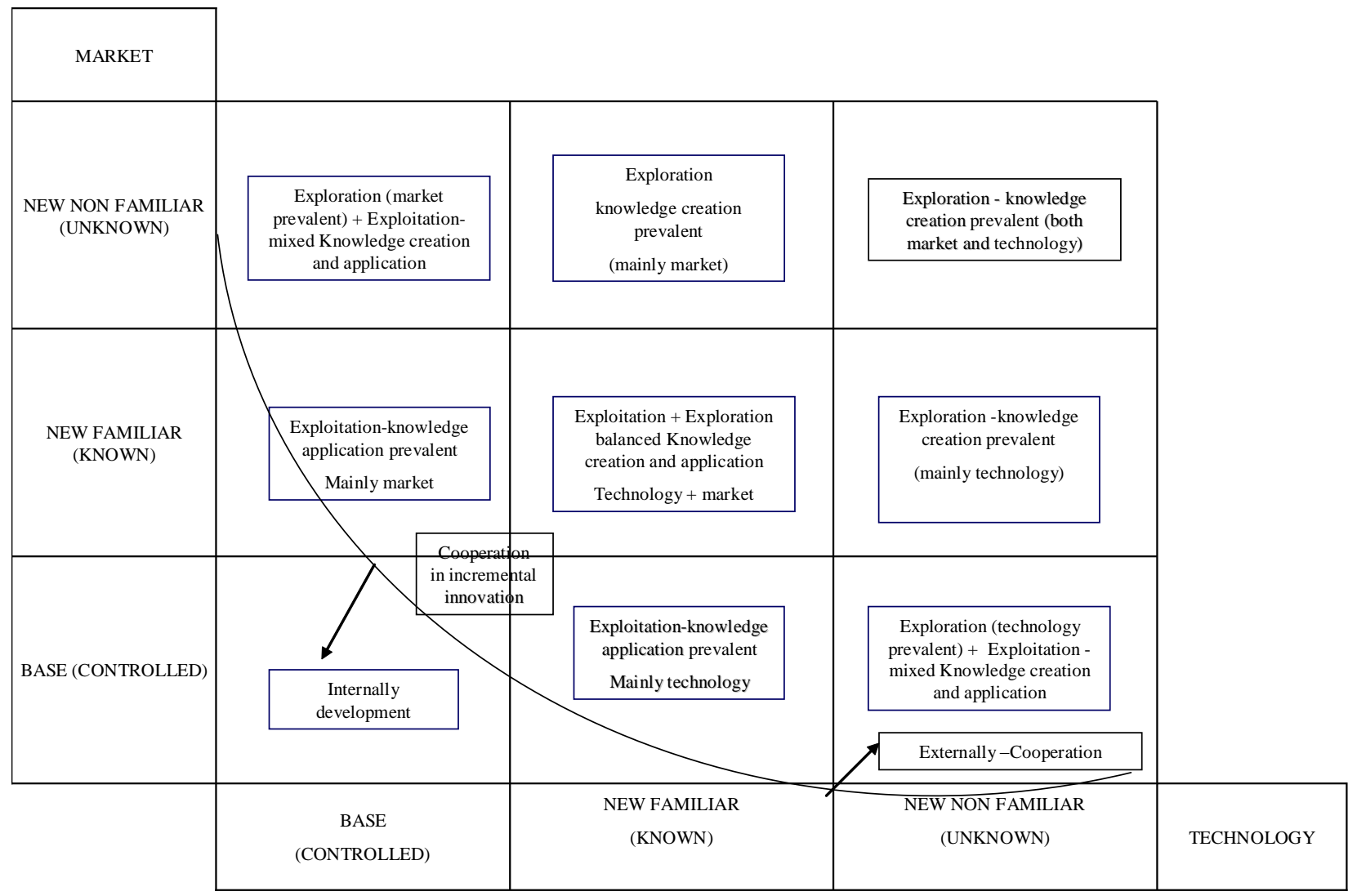

Figure 1: Resources and Knowledge view underpinning one hypothesized matrix. Source: the authors.

The general ideal is that the company, acting as one ambidextrous organization as defined by O' Reilly III and Tushman (2007), could manage one balanced portfolio of non-equity alliance 
projects of different characteristics. In addition, much of the literature on explorative learning focused on exploration activities carried out internally, underestimating an increasingly important exploration activity for companies, that of external corporate venturing, then we will now discuss the learning implications for cooperative alliances, one kind of external venture. The next session brings some ideas about the integration of Portfolio Management and Alliances, a new subject and a new challenge to academics and practioners.

\subsection{Alliances' portfolio management}

Barbosa, Zilber and Toledo (2009) carried out one research investigating 121 Technology Information companies and its use of strategic alliances as catalyzers to the competitive advantages' creation. They have concluded that organization, commitment, focus on shared gains and cooperation are elements favorable to the creation of competitive advantages, specially related to the increase of operational efficiency, agile response and flexibility, pioneer orientation, inovativeness and managerial skills.

The companies can be seen dealing with the knowledge as one way of retaining or acquiring competencies, adapting to the environment. Or inversely, searching for new knowledge (explorative or exploitative) for competing in new segments of the value chain, in this way somehow altering the industry structure and generating some influence in the environment. This study is based mainly in the Resources Based View (RBV) theory. Several researchers have been using this approach, like Das and Teng (2000), Eisenhardt and Schoonhoven (1996), Fritsch and Lukas (2001), Grant and Bade-Fuller (2004), Lavie (2006), Lowe and Taylor (1998), Miotti and Sachwald (2003), Tether (2002) and Veugelers (1995). The RBV of the firm, which builds on Penrose's (1959) pioneering work, considers firms bundles of resources and capabilities. So, the companies own specific resources, but are not selfsufficient in them, depending from other companies for obtaining resources not available internally (Glaister, 1996). The lack of one or more strategic resource or necessary competency is the catalyst for cooperation, which promotes the uncertainty reduction and generates the need to manage this dependency. Capabilities can be defined as the act for adapting, integrating and reconfiguring internal and external organizational skills, resources and functional competencies to match the requirements of changing environment (Verona and Ravasi, 2003). RBV arguments imply that firms also create competitive advantage from resources of alliance partners (Eisenhardt \& Schoonhoven, 1996; Park \& Martin, 2002). Wernerfelt (1984) argued that a firm may derive competitive advantage from resources that are semi-permanently tied to the firm. Along the same line, Henderson and Cockburn (1994)

Revista de Administração e Inovação, São Paulo, v. 11, n.2, p. 241-272, abr./jun. 2014. 
showed that the ability to access new knowledge outside the organizational boundaries is a particularly important source of enduring competitive advantage in research and development (R\&D) productivity. Firms can access external resources via market exchanges, strategic alliances, mergers, and/or acquisitions. Prior research suggested that strategic alliances are a popular way to obtain critical resources for most firms (Eisenhardt \& Schoonhoven, 1996). Although alliances provide only partial access to resources of partner firms, merging with or acquiring an entire firm is complicated and may require significant regulatory approval. The RBV perspective allows understanding the performance implications of alliances by identifying unique characteristics and critical resources in the cooperation. In this study it is also adopted the knowledge theory, as knowledge can be considered one kind of resource in the RBV theory. In fact, these two theories are not so different in content, but diverge in the emphasis given, e.g. the consideration of the kind of knowledge searched and the absorptive capacity of the firm, in the last. The Grant and Bade-Fuller (2004) and Verona and Ravasi (2003) studies advocate new approaches, embodying knowledge in the RBV theory, as a more dynamic framework. The Resource Based View (RBV) and Knowledge Based View (KBV) present quite the same reasoning, resources. According to Roman (2009): "There are many similarities between the resource-based view, the knowledge-based view and the social capital perspective, as all of them view resources as a main source of competitive advantage for firms. They emphasize the importance of inter-organizational relationships in the creation of new resources and in the combination of existing resources. Whilst the resource-based view examines all types of resources, the knowledge-based view focuses on knowledge-based resources and social capital theory focuses on relational resources".

\subsection{Relating the conditions versus the type of alliance}

Araujo and Teixeira (2010) studied the variety of essential requisites for the formation and success of $R \& D$ aliances by means of three $R \& D$ aliances in-depht analyses. They found the requisites varied and were grouped in three phases of the alliance - the formation, negotiation and execution. For instance, in the formation phase, the selection skills are fundamental, and the companies must seek partners that complement their capacities, mainly technological. So, they developed one generic model to guide the essential aspects in each phase of the alliance. So, in the formation phase is crucial to search the more suitable partner, depending on the specific objectives.

In terms of possible players, one alliance can be dealt with customers, suppliers, universities and research institutes (RI's) and competitors. Based on the RBV and KBV logics, the alliance can have two main motivations: the search for complementary resources between the partners - to fill the

Revista de Administração e Inovação, São Paulo, v. 11, n.2, p. 241-272, abr./jun. 2014. 
existing gaps, or similar resources - searching for rapid growth and leadership and for leveraging scales gains and rationalize R\&D efforts (critical mass). Each alliance would be one combination of such objectives in different proportions, depending on the kind of resources that are jointed (Grant \& Bade-Fuller, 2004; Miotti \& Sachwald, 2003; Park \& Martin, 2002; Park, Mezias \& Song, 2004; Starapoli, 1998; Tether, 2002). In the first situation - complementary resources, the more usual type of cooperation is with suppliers or clients, the namely vertical cooperation (Verspagens \& Duysters, 2004), very important in R\&D access to resources as technologies, markets and markets particularities information. The cooperation with suppliers was studied by Sako (1994), Liker, Kamth, Wasti \& Nagamachi (1996) and Bidault, Despres \& Butler (1998), in Japanese companies, and by Tether (2002), in American and European companies, which have passed for "downsizing" and have concentrated in core-activities. The premises for alliances with suppliers are the complementation of internal efforts of $R \& D$, more than the replacement of that. The cooperation with clients has notably importance for reducing the market uncertainties (Balachandra \& Friar, 1997; Kotabe \& Swan, 1995; Savioz \& Sannemann, 1999; Turpin, Garret \& Rankin, 1996), by means of knowledge transfer related to market targets, prices, consumer preferences, and the consequent higher probability of achieving the commercial success for the launched products (Shaw, 1994). And the vertical alliances with Universities and Research Institutes are especially attractive in the case the company needs of intensive R\&D efforts, beyond its capacities of knowledge and infra-structure (Archibugi \& Coco, 2004; Arora \& Gambardella, 1990).

On the other hand, in the namely horizontal alliances, performed between competitors, the companies ally each one putting complementary or non-complementary resources, but generally searching for the risks reduction or costs reduction. Although this, in this kind of cooperation one usual attention is given to the competitive risk, as pointed by Cassiman and Veugelers (1998) and Bruno and Vasconcellos (2003), wherewith the companies need to evaluate, balancing the incentives and risks of cooperation in R\&D (Cassiman \& Veugelers, 1998; Hagedoorn, 1993; Powell, Kogut \& Smith-Doerr, 1996). So, the alliances with competitors seem to be suitable in situations which had been identified one strong mutual objective, with the allocation of complementary resources for the R\&D efforts (as the development of a new drug in the pharmaceutical sector) or when the alliance contributes to changing the competitive environment. This kind of alliance is carried out mainly in big projects, in which the resources demanded and the risk exposure exceed the capacity of each company acting separately, or in case the companies acting in the same segment and experimenting similar problems, look widening the access to resources, not always of the complementary ones (Miotti \& Sachwald, 2003; Tether, 2002). For instance, this kind of cooperation arrangement happens frequently in high 
technological sectors, like the pharmaceutical and chemical industries, and in big projects (Garcia \& Velasco, 2004; Miotti \& Sachwald, 2003, Takayama, Watanabe \& Griff-Brown, 2002).

\subsection{The partner selection factors}

It is practically impossible to one company to maintain its competitive advantage without the adoption of external cooperation activities (Jonash \& Sommerlatte, 1999). The new paradigm conciliates internal and external efforts, as suggested by the Open Innovation model which emphasizes the systematic collaboration among involved parties (Chesbrough, 2003). And in this context, the partner selection is considered the most important activity to the alliances formation process (Dacin, Hitt \& Levitas, 1997; Elmulti \& Kathawala, 2001; Sorensen \& Reve, 1998), but generally underestimated (Koza \& Lewin, 2000; Medcof, 1997; Stafford, 1994). Although this importance, only recently the managers started to give major importance to this important decision (Ariño, Abramov, Skorobogatykh, Rykounina \& Vilá, 1997). The choice of the most indicated partner is crucial to the selection process (Dacin, Hitt \& Levitas, 1997; Devlin \& Bleackley, 1988; Hitt, Dacin, Levitas, Arregle \& Borza, 2000). In fact, there is a lack of prescriptive models to help this decision making, especially considering the specific demands of the project nature - micro level, and the present study aims to fulfill this gap. Analyzing the wide literature describing the alliances cases, we can hypothesize that several alliances could originate from specific demands. In this way, more attention needs to be devoted to the specific demands of the projects, at the project level. In other words, we hypothesize from the episodes analyzed empirically that the specific demands are important and predominant drivers for constituting the alliance, and the companies decide mainly based on it. In this study we have used the classical Geringer typology (1991), dividing the factors for selection in two categories: task related factors and partner related factors, but deepening the comprehension of the task related factors in the field, converted in projects demands and characteristics, and including the intendend objectives for that alliance.

Revista de Administração e Inovação, São Paulo, v. 11, n.2, p. 241-272, abr./jun. 2014. 


\section{METHODOLOGY}

\subsection{Conceptual model and variables operationalization}

Based on the literature review, we built one conceptual model to drive the election of categories and variables to be used in the field. The chart 1 shows the theoretical base used for extracting the variables of the study.

Chart 1: Variables Scales for the Research

\begin{tabular}{|c|c|c|c|}
\hline Category & Variables & Authors base & Operationalization \\
\hline $\begin{array}{l}\text { Intended outcomes at the } \\
\text { partner selection stage. }\end{array}$ & 7 & Contractor and Lorange (1998) & 1 (low) to 5(high) scale \\
\hline Task related factors & 5 & $\begin{array}{c}\text { Geringer (1991); Geringer and } \\
\text { Fraine (1993); } \\
\text { Roberts and Berry (1985) }\end{array}$ & 1 (low) to 5(high) scale \\
\hline Partner related factors & 4 & $\begin{array}{c}\text { Geringer (1991); Geringer and } \\
\text { Fraine (1993) }\end{array}$ & 1 (low) to 5(high) scale \\
\hline Type of project & 1 & Clark and Wheelright (1993) & $\begin{array}{l}4 \text { categories (incremental, platform, radical } \\
\text { and basic science) }\end{array}$ \\
\hline Type of partner & 1 & $\begin{array}{l}\text { Several authors described in } \\
\text { the topic } 2.7\end{array}$ & $\begin{array}{l}5 \text { categories (C: customer; Co: competitor; } \mathrm{S} \text { : } \\
\text { supplier; } \mathrm{U} \text { : university; RI: research institute)., }\end{array}$ \\
\hline
\end{tabular}

The Fig. 2 summarizes the conceptual model, grouping the main dimensions used in the partner selection and the consequent variables adopted, depending on the kind of capabilities searched, the type and characteriscs of the partner and the intended objectives. 


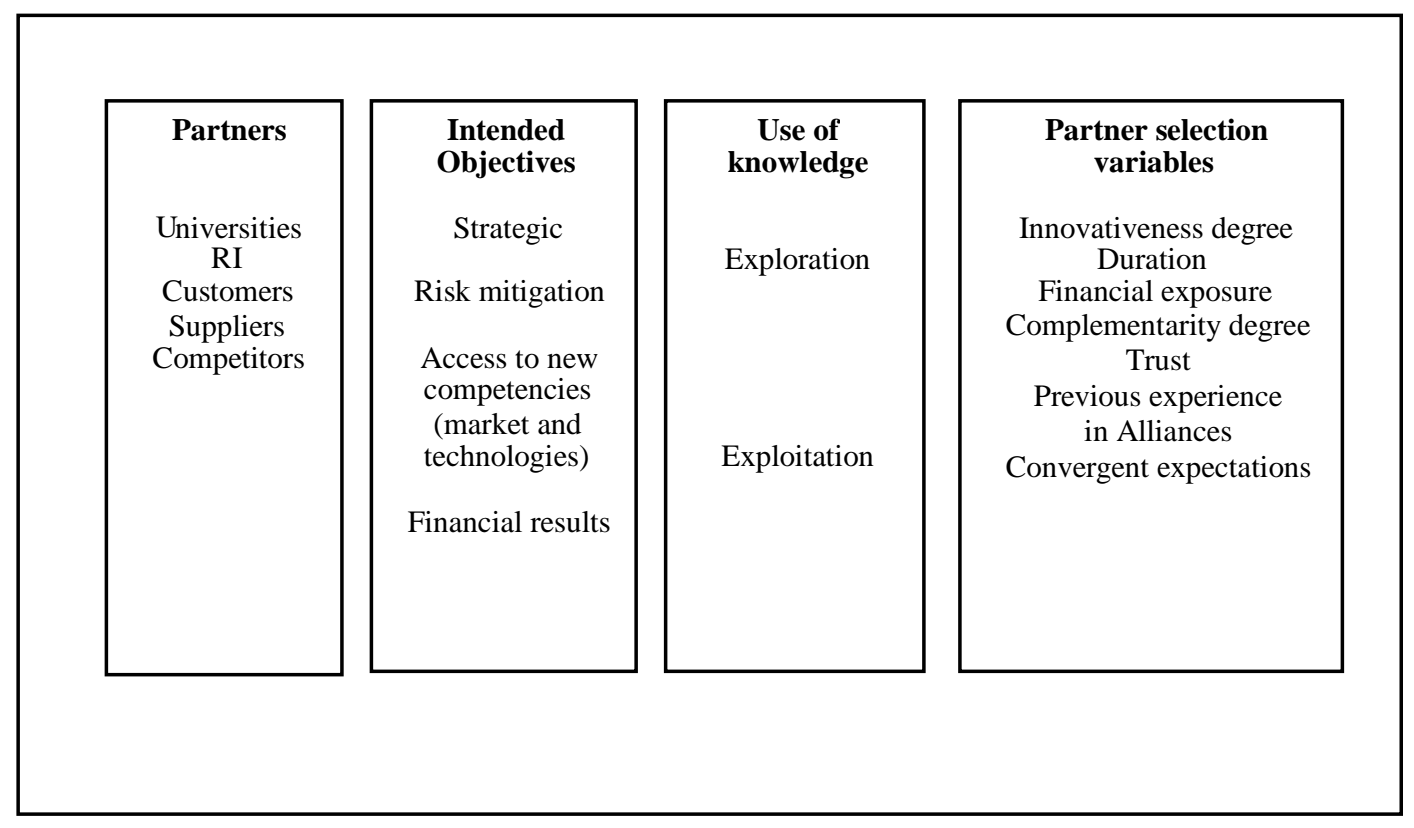

Figure 2: Partner selection conceptual model.

Source: the authors.

Related to the factors considered in the conceptual model, the task related factors are prevalent compared to the partner related factors, as the focus is to establish relations among the different characteristics of the projects and the kind of partner delivering the necessary "resources". This reasoning is supported by the empirical findings of some studies, like Al-Khalifa and Peterson (1999) and Eisenhardt and Schoonhoven (1996), which have argued that for the selection of partner phase (formation phase), the task related factors are significantly more important than the partner related factors, being the dominants of the process. In the same direction, for Al-Khalifa and Peterson (1999) the task related factors are more important in the formation phase, and the partner related factors assume greater significance in the implementation phase. Also Geringer (1991) points that the partner related factors assume major importance in the case of multilateral alliances (multiple partners), which are not the focus of this research.

\subsection{The case studied}

The case study was carried out in one big sized Brazilian petrochemical company, using the single case incorporated, as defined by Yin (2001). In this case, the units of analyses are the most relevant alliances' projects in this company in the last years, from the interviewed perception. We search in this methodology the identification of similarities and divergences among the units. This research is inductive, where we conducted several interviews collecting qualitative data for analyses 
and generation of the theoretical propositions. In this study we have addressed only non-equity bilateral alliances, defined as: "Venturing through non-equity alliances aims at the development of new businesses together with an external partner. In contrast to direct minority investments and joint ventures, non-equity alliances are based on contracts and do not use ownership in the relationship. This form of relationship is used for developing internal ventures or create a framework for joined business development" (Doz \& Hamel, 2000). The company has had annual revenues of more than 10 Billion Dollars in 2008, and has 18 facilities in Brazil. The company was chosen due to pertain to high technological sector, searching for rapid internationalization, and due to the the presence of one wide and diverse array of non-equity alliances it has performed in the last years, related to number and diversity. We carried out the case study addressing twenty relevant alliances episodes in this company. The interviews were carried out with the Corporate Innovation and Technology Director, working for 25 years in the company, and until last year responsible by the Innovation and Technology Directory of the BU's. The alliances episodes under analyze are described in the chart 2, pointed by the interviewed as the more relevant alliances performed in the last years.

Chart 2: Episodes of alliances investigated

\begin{tabular}{|c|c|c|c|}
\hline \# Episode & Project tipology & Partner & Characteristics \\
\hline 1 & $\begin{array}{l}\text { Product platform - } \\
\text { Green polyethylene for } \\
\text { auto parts }\end{array}$ & International customer & $\begin{array}{l}\text { Polyethylene produced from alcohol } \\
\text { generated from sugar cane source }\end{array}$ \\
\hline 2 & $\begin{array}{l}\text { Product platform and } \\
\text { incremental innovation }\end{array}$ & National customer & Compounds from green plastics \\
\hline 3 & Product platform & International customer & Green polyethylene for cosmetics packages \\
\hline 4 & Radical & National customer & $\begin{array}{l}\text { Special fibers for naval use in petroleum } \\
\text { platforms }\end{array}$ \\
\hline 5 & Radical & $\begin{array}{c}\text { Private research institute } \\
\text { owned by big size } \\
\text { supplier }\end{array}$ & $\begin{array}{c}\text { New catalysers and energy generation from } \\
\text { biomass }\end{array}$ \\
\hline 6 & Basic science & University & Renewable sources generation research \\
\hline 7 & Basic science & University & $\begin{array}{c}\text { Polymer development from renewable } \\
\text { sources }\end{array}$ \\
\hline 8 & Basic science & University & Photosynthesis in algae \\
\hline 9 & $\begin{array}{l}\text { Radical and Basic } \\
\text { science }\end{array}$ & University & $\begin{array}{l}\text { Bioreactors for producing polymers from } \\
\text { alcohol generated from algae }\end{array}$ \\
\hline 10 & Basic science & University & Genetic modification of algae \\
\hline 11 & $\begin{array}{l}\text { Basic science and } \\
\text { radical }\end{array}$ & University & $\begin{array}{l}\text { Open ecosystems development for producing } \\
\text { algae }\end{array}$ \\
\hline 12 & $\begin{array}{l}\text { Basic science and } \\
\text { radical }\end{array}$ & International University & $\begin{array}{l}\text { Nanocomposites and nanofibers development } \\
\text { from cellulose }\end{array}$ \\
\hline 13 & $\begin{array}{l}\text { Radical and process } \\
\text { platform }\end{array}$ & Public research institute & Recycling process development \\
\hline 14 & Process platform & Public research institute & $\begin{array}{c}\text { Generation of synthesis gas for petrochemical } \\
\text { plants }\end{array}$ \\
\hline 15 & $\begin{array}{l}\text { Radical and Basic } \\
\text { science }\end{array}$ & $\begin{array}{l}\text { Public research institute } \\
\text { - bridge for Universities }\end{array}$ & Green polypropylene development \\
\hline
\end{tabular}




\begin{tabular}{|c|c|c|c|}
\hline 16 & Incremental & International Competitor & $\begin{array}{c}\text { New plant agreement for production from gas } \\
\text { route }\end{array}$ \\
\hline 17 & Product platform & International customer & $\begin{array}{c}\text { Bioadditive for fuels - Additive from } \\
\text { improving octanage and performance of the } \\
\text { engine. }\end{array}$ \\
\hline 18 & $\begin{array}{c}\text { Basic science and } \\
\text { Radical }\end{array}$ & University & Active (intelligent) packaging \\
\hline 19 & Incremental & International Competitor & $\begin{array}{c}\text { New plant agreement for production from gas } \\
\text { route }\end{array}$ \\
\hline 20 & Product platform & Supplier & Ultra clarified polypropylene \\
\hline
\end{tabular}

\section{RESULTS AND ANALYSES}

\subsection{The Innovation strategic alignment process}

Since 2008, the technological and R\&D activities are structured in two complementary functions: one Innovation and Technology Directory, hierarchical linked to the two business units (BU's) and responsible for the short and medium term activities, and another Directory, called Corporate Innovation and Technology, responding to the Corporate Superintendence and dealing with technology updating and long term developments. This new area absorbs the more complex, risky and uncertain projects, generally presenting higher potential financial returns compared to the other area. In the average, its projects present a RANPV (Risk Adjusted Net Present Value) of 12:1 and 3 to 10 years for completion, compared to a RANPV of 4,2 and 0 to 3 years for completion in the another area. The company was adopting one fast-follower strategy until few years ago, but has changed to one more aggressive leadership strategy nowadays, searching for more international presence and long term technological planning. The technological strategic alignment is guaranteed by the Innovation Management, structured six years ago. Several activities supported the medium and long term planning: first, by means of using technological vigilance techniques, the company has generated the global patents maps. In the sequence, using data mining, were generated the in-depth key words list, which were related to the patents maps. Finally, the company was able to build the technology roadmaps for the specific businesses. As a result of this process, the company defined very well one matrix of key competencies, both the short and long term, and customized for each country, in terms of markets and raw-materials availability. From this matrix, the company has elected the four priority platforms for growth and innovation, where the projects are elected and organized: (i) Carbon Dioxide $\left(\mathrm{CO}_{2}\right)$ Absorption, consisting in the use of marine algae in reactors for alcohol production, used for polymerizing plastics monomers; (ii) Renewable Raw Materials, considering in this category new raw materials and green plastics, obtained from alcohol generated from sugar cane; (iii) high performance 
fibers, i.e., naval fibers for supporting petroleum platforms, and (iv) recycling, including biomass energy generation derived from plastic waste. So, the company searches for projects and competencies within these four platforms, internal or external, sharing resources, risks and accelerating the projects with alliances. The partners are selected based on one analytical array of criteria, not completely formalized and it varies depending on the project objective. This evidence gives support for the theoretical framework used in this paper.

\subsection{Partner selection criteria in the company}

We have assessed diversified technological alliances episodes and its contributing factors for selecting partners, in order to obtain data richness, validating the literature review and checking the appearance of new evidences for composing the analytical framework for the sector analyzed, and, in the sequence, we have analyzed the evidences carrying out several grouping analyses in order to generate the theoretical propositions.. In the episodes analyzed, the most important criteria identified for selecting the partner in the alliances is the search of resources' complementarities and competences that complement the gaps of the enterprise for that project. Generally, the alliances with Universities are related to basic science or breakthroughs projects. So, the company carries out specific expertise mapping and analyses, avoiding expertise's overlapping among the different universities. The cooperation with Universities initiates with the clear identification of its expertise in each one. In the sequence, the company does workshops with the Universities presenting the research lines. So, the Universities indicate the research centers and researchers more suited to these themes and the negotiation starts. The patents and intellectual rights properties are shared between the company and its partners. Contrasting with these alliances with Universities, the alliances with Research Institutes are more dedicated to applied science, i.e., new platforms of products or process. In the words of the interviewed: "The Research Institutes engage very well with applications, they become that development one reality. But instead the Universities, the RI's do not have so focused capabilities for the basic research, being enough to compare the structures and team education, specially the number of PhDs. While one Brazilian RI can have only three PhD's in the whole structure, one top front University, as the UFSCar, has around 98\% PhD's". The interviewed completes the rationale of diverse roles, and states: "On the other hand, the Universities do not have capabilities for technology application. For a long time there had been confusion in the different roles of these players, and the Research Institutes were seen as rivals to the Universities, trying to conduct basic research, what naturally were not their core competence. But nowadays the focus is clearer for both, RIs and

Revista de Administração e Inovação, São Paulo, v. 11, n.2, p. 241-272, abr./jun. 2014. 
Universities". The alliances with customers in general present high complementarities search, the parent company providing the technical expertise and the customer the market expertise. Moreover it was possible to identify the necessity of analyzing convergent interests and balanced financial capacity. In the alliances with suppliers the previous relationship is inverted, i.e., the technological expertise is given by the supplier, and the parent company contributes more with its market expertise. Finally, in the alliances with competitors, is possible to notice one major orientation towards risks reduction by means of investments and $R \& D$ assets sharing, indicating the prevalence of similar resources usage.

In terms of the selection process, the data confirm that it strongly takes into account the specific characteristics of the projects, and moreover, considers them the most important aspects in the first moment. So, the RBV and KBV backgrounds appear to be so suitable and coherent to analyze the partner selection at micro level, remembering we are not analyzing performance issues, what also depends heavily of the detailed social perspective of the partnership, and can be analyzed in one second selection phase. These second phase aspects as integration and knowledge management issues can receive detailed attention in the alliance implementation. According to the interviewed, "the partner searched competencies for that project; the clarity of purposes and the trust in the partner are the main criteria for the first screen analyses. Along the time, the companies learn to work together, and unless the organizational differences are so big, they can achieve convergence in the working system". And he adds:" The historical of prior partnerships by the partner is one guaranty of the existence of organizational culture for alliances. And if we have had prior alliance with that partner, we are safe we will not have big problems". It gives support to one preliminary screen step mainly at project level, prioritizing the analyses based on resources and projects elements, presenting project level preponderance. It can be followed for one firm level second step, based on detailed aspects from organizational cultures - social approach, and in its integration and knowledge management mechanisms - knowledge approach. In the case analyzed, the company forms blogs and practice communities for helping the integration. Besides that, most of times they build autonomous teams between the partners aiming to guarantee focus to the alliance. In the alliances with Universities, the company defines one leader that consolidates and communicates the advancements results twice a month. Most of variables identified from the literature review and presented in the sequence, were confirmed by the qualitative empirical data collected as task related factors or partner related factors that contribute for selecting the partner, validating their presence for the next quantitative step of the research: the access to similar or complementary resources; the project's technological and market familiarity degree, both of the enterprise and the partner, translating to technological and market

Revista de Administração e Inovação, São Paulo, v. 11, n.2, p. 241-272, abr./jun. 2014. 
complementarities degree; the involved risk of the project, deployed in financial, technological, market and competitive risks; the project's time for completion; the resources demand necessary for developing the project; the previous experience in alliances of the partner and the previous experience in alliances with that partner; the trust in the partner regarding contract attendance and confidentiality, the trust in the partner regarding the attendance to project terms and flexibility to adjusts, the trust in the partner regarding its own competencies, the trust in the partner regarding existence of management process that contribute to interaction and integration. Also the type of innovation in terms of its innovativeness degree appeared as one important factor. New evidences arise from the case studies, being one the importance of convergent expectations between the partners for the continuity of the alliance, expressed specifically by the financial capacity of the partner for continuing the investments, what absence can depress the alliance performance and must be considered in the selection stage. So, although in the literature the asymmetries can be treated as positive factors, if they are so broad, they can generate problems on implementing the necessary investments and generate disagreements. Other evidence, mainly in alliances with companies from other sectors or competitors, refers to the access to new sources of raw materials enabled by the partner, national or international. Also the clear definition of objectives and goals from both partners is one sine qua non factor for constituting the alliance. The following intended objectives for selecting the partner, derived from the literature, were also confirmed in the field study: partner convergent expectations for starting the project; strategic objectives expectations; sharing of financial investments expectations, $R \& D$ competences expectations and market competences expectations; partner geographic category and organizational culture differences (which must not be so diverse, in this way enabling the good relationship and interaction).

\subsection{Main evidences collected from the cases}

In the chart 3 are summarized the main evidences collected in the field, in terms of the main drivers for collaborating with that specific partner, the kind of project and the main characteristics of the projects, based on assessing the partner selection factors by means of the in-depht qualitative investigation derived from the interviewed narrative and also the degree of presence of the variables, as shown in table 2 , placed in the end of the article.

Revista de Administração e Inovação, São Paulo, v. 11, n.2, p. 241-272, abr./jun. 2014. 
Chart 3: More prevalent situations of the partnership - general evidences from the cases.

\begin{tabular}{|c|c|c|c|}
\hline $\begin{array}{l}\text { Type of } \\
\text { partner }\end{array}$ & $\begin{array}{c}\text { Main drivers for } \\
\text { collaborating with that } \\
\text { partner }\end{array}$ & More frequent type of project & $\begin{array}{c}\text { Main characteristics of the } \\
\text { projects }\end{array}$ \\
\hline Competitor & - Access to similar resources & - Incremental innovations & $\begin{array}{l}\text { - Big projects } \\
\text { for installing new plants } \\
\text { - International agreements }\end{array}$ \\
\hline Customer & $\begin{array}{l}\text { - Access to complementary } \\
\text { technical resources } \\
\text { - Access to new markets }\end{array}$ & $\begin{array}{l}\text { - Radical innovation } \\
\text { widening use for opening new } \\
\text { markets } \\
\text { Product platforms for new } \\
\text { markets }\end{array}$ & $\begin{array}{l}\text { - National } \\
\text { or International } \\
\text { - Downstream }\end{array}$ \\
\hline Supplier & $\begin{array}{l}\text { - Enabling solutions and } \\
\text { improvements for products } \\
\text { (maybe for processes too) }\end{array}$ & $\begin{array}{l}\text { - Product platforms } \\
\text { - maybe for processes too }\end{array}$ & $\begin{array}{l}\text { - Medium projects in terms of } \\
\text { capital needs } \\
\text { - Medium uncertainty } \\
\text { - Upstream }\end{array}$ \\
\hline $\begin{array}{l}\text { Research } \\
\text { Institute } \\
\text { (RI) }\end{array}$ & $\begin{array}{l}\text { - Access to complementary } \\
\text { technical resources or to } \\
\text { similar technical resources } \\
\text { (R\&D structure) }\end{array}$ & $\begin{array}{l}\text { - Product platforms or Process } \\
\text { platforms }\end{array}$ & $\begin{array}{l}\text { - Application focus } \\
\text { - Or Orchestration behavior- } \\
\text { RI linking universities } \\
\text { efforts }\end{array}$ \\
\hline University & $\begin{array}{l}\text { - Access to complementary } \\
\text { technical resources } \\
\text { (knowledge) } \\
\text { - Faster the development }\end{array}$ & $\begin{array}{l}\text { - Basic Science or Radical } \\
\text { Innovation first development }\end{array}$ & $\begin{array}{l}\text { - Long term } \\
\text { - High uncertainty }\end{array}$ \\
\hline
\end{tabular}

For this paper purpose, under the qualitative approach, it was also possible to plot the 20 episodes, in terms of the technological and market familiarity that the parent company possesses in each alliance, which enabled the identification of some partners and projects domains (Fig. 3). It is possible to notice these patterns of the alliances positioned in the exploitation-exploration continuum, depending on the type of partner, kind of knowledge being accessed and the type of innovation project, determining some domain regions according to the nature of the analyzed episodes. This simple matrix can be useful for the partnerships decision making, choosing partners which rationally complement the weaknesses of the parent company regarding the projects characteristics - attaining market and/or technological competences externally. 


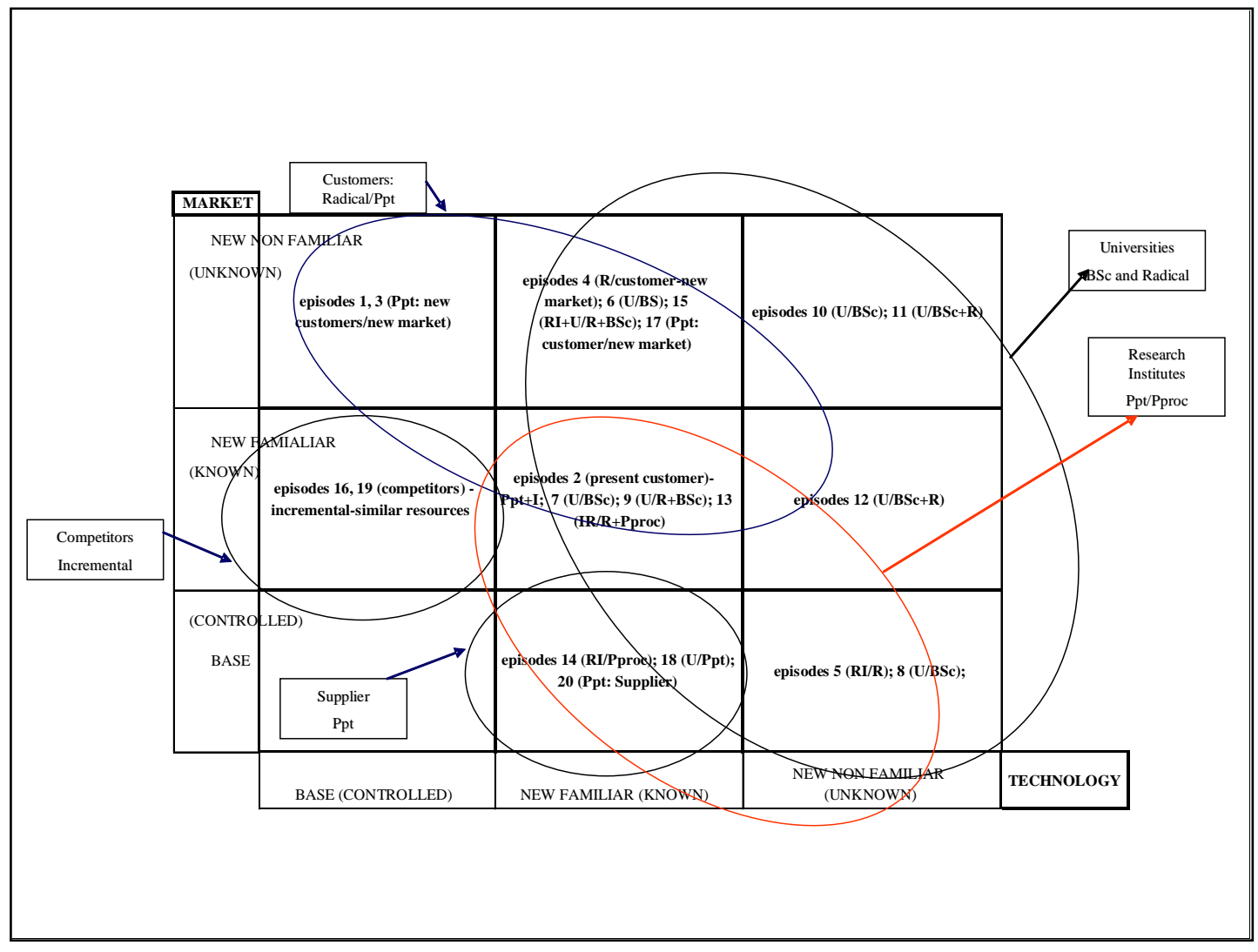

Figure 3: Positioning of the alliances' episodes in the exploitation-exploration continuum. Source: The authors.

\subsection{Theoretical propositions generated from the qualitative study}

Based in the qualitative patterns identified in the study it was possible to build some theoretical propositions. The general premise of the research was that specific characteristics of the projects influence in the decision for choosing the more indicated partner in non-equity bilateral technological alliances. And these characteristics probably show divergences, accordingly with the nature of the partner and the nature of the project. Considering the exploratory nature of the research and the lack of studies and evidences dealing with the specific factors for selecting partners at the project level, the theoretical propositions are generated based mainly in the qualitative evidences that have emerged from the case studies, although they are underpinned also by the literature review, as discussed in the topic 2.7. In the chart 4 are shown the theoretical propositions derived from the qualitative data, more specifally extracted from the evidences detailed presented in table 2 - placed at the end of the article (containing ordinal scales for the variables, from low to high presence of the variable in that specific alliance), and treated by means of establishing divergences between the goups presented in the propositions. Although the data are qualitative in its nature, the ordinal data of table 2 were converted 
to numerical scale (low=1 to high=5), in order to compare the variable score for different grouping of categories and to build the theoretical propositions shown in the chart 4 .

\section{Chart 4: Theoretical propositions generated from the cases}

\begin{tabular}{|c|}
\hline Theoretical propositions \\
\hline $\begin{array}{l}\text { P1: The project resources demand is higher in alliances with Universities and Research Institutes compared to } \\
\text { alliances with suppliers and customers. }\end{array}$ \\
\hline $\begin{array}{l}\text { P2: The duration of the project is higher in alliances with Universities and Research Institutes compared to alliances } \\
\text { with the other players. }\end{array}$ \\
\hline P3a. The financial risks are higher in alliances with competitores compared to alliances with the other players. \\
\hline $\begin{array}{l}\text { P3.b. The technological risks are higher in alliances with Universities and Research Institutes compared to alliances } \\
\text { with the other players. }\end{array}$ \\
\hline P3.c. The market risks are higher in alliances with customers compared to alliances with the other players. \\
\hline $\begin{array}{l}\text { P3d. The competitive risks are lesser in alliances with Universities and Research Institutes compared to alliances } \\
\text { with the other players. }\end{array}$ \\
\hline $\begin{array}{l}\text { P3e. The competitive risks are higher in alliances with customers and competitores compared to alliances with the } \\
\text { other players. }\end{array}$ \\
\hline $\begin{array}{l}\text { P4a. The technological complementarity occurs in higher levels in alliances with Universities, Research Institutes } \\
\text { and customers compared to alliances with the other players. }\end{array}$ \\
\hline $\begin{array}{l}\text { P4.b. The market complementarity occurs in higher levels in alliances with customers, Universities and Research } \\
\text { Institutes compared to alliances with the other players. }\end{array}$ \\
\hline $\begin{array}{l}\text { P4c. The overall complementarity occurs in higher levels in alliances with Universities, Research Institutes and } \\
\text { customers compared to alliances with the other players. }\end{array}$ \\
\hline $\begin{array}{l}\text { P5: The previous experience in alliances of the partner is more significant in alliances with Universities and } \\
\text { Research Institutes compared to alliances with enterprises. }\end{array}$ \\
\hline $\begin{array}{l}\text { P6. The trust in the partner is more significant in alliances with enterprises compared to alliances with Universities } \\
\text { and Research Institutes. }\end{array}$ \\
\hline $\begin{array}{l}\text { P6a: The trust in the partner regarding project deliverables and flexibility for adjusts is higher in alliances with } \\
\text { customers, suppliers and competitors compared to alliances with Universities and Research Institutes. }\end{array}$ \\
\hline $\begin{array}{l}\text { P6b. The trust in the partner regarding existence of competences is positively related to the technological familiarity } \\
\text { perceived in the partner. }\end{array}$ \\
\hline $\begin{array}{l}\text { P7: The convergence of expectations in the partnership is more significant in alliances with enterprises compared to } \\
\text { alliances with Universities and Research Institutes. }\end{array}$ \\
\hline $\begin{array}{l}\text { P8. The organizational cultural similarity is more significant in alliances with enterprises compared to alliances with } \\
\text { Universities and Research Institutes. }\end{array}$ \\
\hline $\begin{array}{l}\text { P9a: Alliances with international partners are more related to radical innovation projects than the alliances with } \\
\text { national partners. }\end{array}$ \\
\hline $\begin{array}{l}\text { P9b: Alliances with international partners are more related to alliances with customers and suppliers than the } \\
\text { alliances with Universities and Research Institutes. }\end{array}$ \\
\hline $\begin{array}{l}\text { P9c: Alliances with international partners embody higher market risks perception compared to alliances with } \\
\text { national partners. }\end{array}$ \\
\hline $\begin{array}{l}\text { P10a: Basic science and radical innovation projects are more frequently associated to alliances with Universities and } \\
\text { Research Institutes compared to alliances with other partners. }\end{array}$ \\
\hline $\begin{array}{l}\text { P10b: Platform and incremental innovation projects are less associated to to alliances with Universities and } \\
\text { Research Institutes compared to alliances with other partners. }\end{array}$ \\
\hline P10c: The higher the complexity of the project higher the propensity of the alliance be carried out with Universities \\
\hline
\end{tabular}

Revista de Administração e Inovação, São Paulo, v. 11, n.2, p. 241-272, abr./jun. 2014. 


\section{CONCLUSIONS, EXPECTED CONTRIBUTIONS AND LIMITATIONS}

As previously stated, this paper aimed to emphasize the project level attributes in the partner selection process, by means of one qualitative study focusing on technological alliances. In this study, twenty alliance-based projects were analysed and preliminary results point to different patterns depending on the nature of the project, as shown in the chart 3 and figure 3, enabling the inductive generation of several propositions, as shown in the chart 4.

As main conclusions, the study points out some preliminary distinctions and relations among the different alliances drivers, partner type, project type and alliances characteristics. When performed with competitors, the alliances in general search similar resources, are more related to incremental innovation, big projects and international partners. The alliances with customers mainly search for complementary technological resources or new markets, and are more related to radical innovation or product platforms searching new markets. The alliances with suppliers primarily search for existent solutions and products/process enhancements, mainly based in products/processes platforms. More than this, are generally performed in medium sized projects and only relative uncertainty levels. The alliances with Research Institutes are mainly used in product/process platforms and eventually in incremental innovation, with focus on application or integrating the Universities efforts. Finally, the alliances with Universities search for complementary technical resources and accelerating uncertain long term projects, and are more related to basic science projects or first development of radical innovations.

At this moment the study is evolving for the deductive test of the generated propositions. We think that this study can shed light into this important subject both from the theoretical as the practical point of view. From the theoretical point of view by: (i) linking the Alliances strategy literature review with the Corporate Venturing strategies literature, which suggests the same underlying rationale for the decision making analyses; (ii) proposing a new perspective for framing the problem, dealing with the specific characteristics of the projects and of the actors (partners); (iii) discussing new evidences identified about the factors for selecting partners in technological alliances; (iv) trying to fill the identified theoretical gap, analyzing the partner selection also in the project level, introducing aspects for selection related to the characteristics of the projects, since the existing studies until now have analyzed the phenomena mainly from the firm-level point of view. And, from the practical point of view, by proposing the development of one contingency framework that could help the managers in the decision making process regarding the selection of partners.

Revista de Administração e Inovação, São Paulo, v. 11, n.2, p. 241-272, abr./jun. 2014. 
As limitations of this study, the case studies do not allow statistics generalizations, only analytical generalizations. Conclusions are constrained to the companies studied and to the moment that the collect was done (Yin, 2001). As suggestions for future investigation, qualitative studies, in other sectors checking the evidences here found, would be welcomed. And also quantitative studies for testing the propositions generated. It would be also interesting to have cross sectional studies in different contexts, in order to check the sector's influence comparing the low, medium and high tech sectors, according to the OECD's classification.

\section{REFERENCES}

Al-Khalifa, A.K., \& Peterson, S.E. (1999) The Partner selection process in international joint ventures. European Journal of Marketing, 33 (11/12), pp. 1064-1081.

Araujo, S. V. \& Teixeira, F.L.M. (2010). Parcerias em projetos de P\&D: uma relação entre requisitos e fases de cooperação Revista de Administração e Inovação, São Paulo, v. 7, n. 1, pp. 84-108.

Archibugi, D., \& Coco, A. (2004) International partnerships for knowledge in business academia: a comparison between Europe and the USA. Technovation, 24 (7), pp. 517-528.

Ariño, A., Abramov, M., Skorobogatykh, I., Rykounina, I., \& Vilá, J. (1997) Partner selection and trust building in West European-Russian joint ventures: A Western perspective". International Studies of Management and Organization, 27 (1), pp. 19-37.

Arora, A., \& Gambardella, A. (1990) Complementary and external linkages: the strategies of large firms in biotechnology". Journal of Industrial Economics, n. 38, June, pp. 361-379.

Balachandra, R., \& Friar, J.H. (1997) Factors for success in R\&D projects and new product innovation: a contextual framework? IEEE Transactions on Engineering Management, 44 (3).

Barbosa, C. A., Zilber, M.A. \& Toledo, L.A. (2009). A aliança estratégica como fator de vantagens competitivas em empresas de TI - um estudo exploratório Revista de Administração e Inovação, São Paulo, v. 6, n. 1, p. 30-49.

Berger, P. G., \& Ofek, E. (1995) Diversification's Effect on Firm Value. Journal of Financial Economics, 37, pp.39-65.

Bidault, F., Despres, C., \& Butler, C. (1998) The Drivers of Cooperation between Buyers and Suppliers for Product Innovation. Research Policy, 24, pp. 97-114.

Bruno, M. A. C., \& Vasconcellos, E. P. G. (2003) Applying a Management Framework to three Highsharing Technological Alliances". Revista Finanza Marketing e Produzione, vol. 2 (n. XXI), pp.107 126.

Burgelman, R. A., \& Sayles, L. R.(1986) Inside Corporate Innovation. New York: Free Press.

Revista de Administração e Inovação, São Paulo, v. 11, n.2, p. 241-272, abr./jun. 2014. 
Cassiman, B., \& Veugelers, R. (1998) R\&D cooperation and spillovers: some empirical evidence. Universitat Pompeu Fabra, working paper, n. 328.

Chesbrough, H. (2003) Open Innovation: The New Imperative for Creating and Profiting from Technology. Harvard Business School, Boston, MA.

Clark, K. B., \& Fujimoto, T. (1991) Product Development Performance - Strategy, Organization, and Management in the World Auto Industry. Harvard Business School Press.

Clark, K. B., \& Wheelright, S. C. (1993) Managing new product and process development: text and cases. New York: Maxwell Macmillan International, pp.233-289.

Cooper, R. G., Edgett, S. J., \& Kleinschmidit, E. J. (1997) Portfolio management in new product development: lessons from the leaders-II. Research Technology Management, 40 (6).

Cooper, R. G.; Edgett, S. J., \& Kleinschmidit, E. J. (2000) New Problems, new Solutions: making portfolio management more effective. Research Technology Management, 43(2).

Dacin, T., Hitt, M., \& Levitas, E. (1997) Selecting partners for successful international alliances: examination of U.S. and Korean Firms. Journal of World Business, 32(1), pp. 3-16.

Daneels, E. (2002) The dynamics of product innovation and firm competences. Strategic Management Journal, 23, pp. 1095-1121.

Das, T. K., \& Teng, B. (2000) A resource-based theory of strategic alliances. Journal of Management, 26(1), pp. 31-61.

Devlin, G., \& Bleackley, M. (1988) Strategic alliances - guidelines for success. Long Range Planning, 21(5), pp.18-23.

Doz, Y. L., \& Hamel, G. (2000) A Vantagem das Alianças- A Arte de Criar Valor através de Parcerias. Rio de Janeiro: Quality Mark.

Dussauge, P., Hart, S., \& Ramanantsoa, B. (1992) Strategic Technology Management, John Wiley and Sons, pp.90-91.

Eisenhardt, K.M., \& Schoonhoven, C.B. (1996) Resourced-based view of strategic alliance formation: strategic and social effects in entrepreneurial firms, Organization Science, 7(2).

Fritsch, M., \& Lukas, R. (2001) Who co-operates on R\&D? Research Policy, 30, pp.297-312.

Garcia, C. Q., and Velasco, C. B. (2004) Cooperation, competition and innovative capability: a panel data of European dedicated biotechnology firms. Technovation, 24(12), pp. 927-938.

Geringer, J. M. (1991) Strategic determinants of partner selection criteria in international joint ventures. Journal of International Business Studies, first quarter, 22(1), pp. 41-62.

Glaister, K.W. (1996) UK-Western European strategic alliances: motives and selection criteria. Journal of Euromarketing, 5(4), pp. 5-35.

Grant, R., \& Bade-Fuller, C.A. (2004) A knowledge accessing theory of strategic alliances. Journal of Management Studies, 41(1), pp.61-84.

Revista de Administração e Inovação, São Paulo, v. 11, n.2, p. 241-272, abr./jun. 2014. 
Griffin, A., \& Page, A. L. (1997) PDMA success measurement project: recommended measures for product development success and failure. Journal of Product Innovation Management, 13, pp. 478496.

Hagedoorn, J. (1993) Understanding the rationale of strategic technology partnering: interorganizational modes of cooperation and sectoral differences. Strategic Management Journal, 14(5), pp. 371-385.

Henderson, R. M., \& Cockburn, I. M.(1994) Measuring competence? Exploring firm effects in pharmaceutical research. Strategic Management Journal , 15, pp. 63-84.

Hitt, M.A., Dacin, M.T., Levitas, E., Arregle, J-L., \& Borza, A. (2000) Partner selection in emerging and developed market contexts: resource-based and organizational learning perspectives. Academy of Management Journal, 43(3), pp. 449-467.

Hunger, J. D., \& Wheelen, T. L. (1995) Strategic Management and Business Policy. 5 ed. Massachussets: Addison-Wesley.

Jonash, R. S., \& Sommerlatte, T. (1999) The Innovation Premium : How Next Generation Companies Are Achieving Peak Performance and Profitability. Perseus Books Group.

Keil, T. (2002) External Corporate Venturing: Strategic Renewal in Rapidly Changing Industries. Quorum, Westport, CT.

Kotabe, M., \& Swan, K.S. (1995) The role of strategic alliances in high-technology new product development. Strategic Management Journal, 16, pp. 621-636.

Koza, M.P., \& Lewin, A.Y. (2000) Managing partnerships and strategic alliances: raising the odds of success. European Management Journal, 16(2), pp. 146-151.

Kumpe, T., \& Bolwjin, P. T. (1994) Toward the innovative firm - Challenge for R\&D management. Research Technology Management; 37 (1),

Lavie, D. (2006) The competitive advantage of interconnected firms: an extension of the resourcebased view. Academy of Management Review, 31(3), pp. 638-658.

Liebeskind, J., \& Opler, T. C. (1993) The causes of corporate refocusing. Southern Methodist University. Dallas, TX. USA, working paper.

Liker, J.K., Kamth, R.R., Wasti, S.N., \& Nagamachi, M. (1996) Supplier involvement in automotive component design: are there really large US Japan differences? Research Policy, 25, pp. 59-89.

Lowe, J., \& Taylor, P. (1998) R\&D and technology purchase trough licence agreements: complementary strategies and complementary assets. $R \& D$ Management , 28(4), pp. 263-278.

March, J. G. (1991) Exploration and exploitation in organizational learning. Organization Science, 2, pp. 71-87.

Maula, V.J.M. (2001) Corporate venture capital and the value-added for technology-based new firms". Doctoral dissertation, Helsinky University of Technology, Espoo-Finland.

Medcof, J.W. (1997) Why too many alliances end in divorce. Long Range Planning, 30(5).

Revista de Administração e Inovação, São Paulo, v. 11, n.2, p. 241-272, abr./jun. 2014. 
Miotti, L., \& Sachwald, F. (2003) Co-operative R\&D: why and with whom? An integrated framework of analysis. Research Policy,32, pp. 1481-1499.

O’Reilly III, C. A., \& Tushman, M. L. (2007) Ambidexterity as a dynamic capability: resolving the innovator's dilemma. Harvard Business School, working paper, 2007.

Park, N. K., Mezias, J.M., \& Song, J. (2004) A resource-based view of strategic alliances and firm value in the electronic marketplace. Journal of Management, 30(1), pp. 7-27.

Park, N. K., \& Martin, X. (2002) When do resources enhance firm value? Testing alliance and resource effects on firm value. School of Business Administration, University of Miami, Coral Gables, FL, working paper.

Peters, T. (1980) Putting excellence into management. Business Week, July 21, pp. 196-205.

Powell, W.W., Kogut, K.W. \& Smith-Doerr, L. (1996) Interorganizational collaboration and the locus of innovation: networks of learning in biotechnology. Administrative Science Quarterly, 41, pp. 116145.

Roberts, E. B., \& Berry, C. A. (1985) Entering new businesses - selecting strategies for success. MIT Sloan Management Review, Cambridge, MA, spring, pp 3-17.

Roman, M. (2009) Inter-organizational relationships in innovation processes: A microfoundations approach. Doctoral Dissertation, Helsinki Universit, Espoo, Finland.

Roussel, P.A., Saad, K. N. S., \& Bohliw, N. (1992) P\&D: Como integrar P\&D ao Plano Estratégico e Operacional das Empresas Como Fator de Produtividade e Competitividade. São Paulo: Makron Books.

Rumelt, R. P. (1974) Strategy, structure and economic performance. Division of Research, Harvard Business School, Boston.

Rumelt, R. P. (1982) Diversification strategy and profitability. Strategic Management Journal, 3, pp.359-369.

Sako, M. (1994) Supplier relationships and innovation. In: Dodgson, M., Rothwell, R. (Eds.), The Handbook of Industrial Innovation, Edward Elgar, Cheltenham, UK.

Savioz, P., \& Sannemann, E. (1999) The concept of the integrated innovation process. Proceedings of the PICMET'99, eds Kocaoglu, D. F. \& Anderson, T. R., Portland-USA.

Schilling. M.A., \& Hill, C.W.L. (1998) Managing the new product development process: strategic imperatives, Academy of Management Executive, 12(13), pp. 67-81.

Shaw, B. (1994) User-supplier links and innovation. In: Dodgson, M. and Rothwell, R. (eds.), The Handbook of Industrial Innovation. Edward Elgar, Cheltenham, UK.

Sorensen, H.B., \& Reve, T. (1998) Forming strategic alliances for asset development. Scandinavian Journal of Management, 14(3), pp. 151-165.

Stafford, E. R. (1994) Using co-operative strategies to make alliances work. Long Range Planning, 27(3), pp. 64-74.

Revista de Administração e Inovação, São Paulo, v. 11, n.2, p. 241-272, abr./jun. 2014. 
Starapoli, C. (1998) Cooperation in R\&D in the pharmaceutical industry - the network as an organizational innovation governing technological innovation. Technovation, 18(1).

Takayama, M., Watanabe, W., \& Griff-Brown, C.H. (2002) Alliance strategy as a competitive strategy for successively creative new product development: the proof of the co-evolution of creativity an efficiency in the Japanese pharmaceutical industry. Technovation, 22 (10).

Tether, B.S. (2002) Who co-operates for innovation, and why. An empirical analysis. Research Policy, 31, pp. 947-967.

Tritle, G.L., Scriven, F. V., \& Fusfeld, A. R. (2000) Resolving uncertanty in R\&D portfolio. ResearchTechnology Management, 43(6), pp 47-55.

Turpin, T., Garret, J.S., \& Rankin, N. (1996) Bricoleurs and boundary riders: managing basic research and innovation knowledge networks. $R \& D$ Management , 26(3), pp. 267-282.

Verona, G., \& Ravasi, D. (2003) Unbundling dynamic capabilities: an exploratory study of continuous product innovation. Industrial and Corporate Change, 12(3), pp.577-606.

Verspagens, B., \& Duysters, G. (2004) The small worlds of strategic technology alliances. Technovation, 24(7), pp. 563-571.

Veugelers, R. (1995) Alliances and the pattern of cooperative advantages. International Business Studies, n. 4, p. 213-231.

Wernerfelt, B. (1984) A resource based view of the firm. Strategic Management Journal, 5.

Yin, R. K. (2001) Estudo de Caso - Planejamento e Métodos. Porto Alegre: Bookman, 2001. 


\section{FATORES DE SELEÇÃO DE PARCEIROS EM PROJETOS DE INOVAÇÃO - EVIDÊNCIAS EM ALIANÇAS DO LÍDER PETROQUÍMICO BRASILEIRO}

\section{RESUMO}

Em função da limitação de recursos, necessidade de aceleração dos desenvolvimentos e a falta de algumas competências internamente, as empresas são levadas a cooperarem com agentes externos, como outras empresas e universidades, como sugere o paradigma da Inovação Aberta. Apesar da existência de muitos estudos tratando dos fatores de seleção de parceiros em alianças no nível da empresa, poucos estudos se dedicaram a entender as demandas específicas da tarefa, em nível de projeto, considerada a lacuna teórica a ser endereçada nesse estudo. O artigo aborda a análise dos fatores de seleção de parceiros em projetos de alianças bilaterais, dependendo do tipo de parceiro e do tipo de projeto de inovação. Os dados derivam do estudo de caso de uma empresa petroquímica brasileira, por meio da análise em profundidade de 20 projetos de alianças com diferentes parceiros concorrentes, clientes, fornecedores, universidades e incorporando diferentes graus de inovação inovação incremental, plataforma, radical e investigação de ciência básica. Baseado na Visão baseada em recursos (VBR), foi possível identificar os fatores de seleção de parceiros mais prevalecentes e as características das alianças, dependendo do tipo de parceiro e tipo de projeto. A base teórica investigada, em conjunto com as evidências qualitativas encontradas, permitiram a construção de um conjunto de proposições teóricas passíveis de testes em estudos quantitativos futuros..

Palavras-chave: Gestão da inovação; Alianças tecnológicas; Seleção de parceiros.

Data do recebimento do artigo: 04/12/2013

Data do aceite de publicação: 19/04/2014

Revista de Administração e Inovação, São Paulo, v. 11, n.2, p. 241-272, abr./jun. 2014. 
Marcos Paixão Garcez, Roberto Sbragia \& Isak Kruglianskas

Table 2: Alliances' episodes data

\begin{tabular}{|c|c|c|c|c|c|c|c|c|c|c|c|c|c|c|c|c|c|c|c|c|}
\hline & \multicolumn{20}{|c|}{ Episodes number } \\
\hline Variables & 1 & 2 & 3 & 4 & 5 & 6 & 7 & 8 & 9 & 10 & 11 & 12 & 13 & 14 & 15 & 16 & 17 & 18 & 19 & 20 \\
\hline Partner category & $\mathrm{C}$ & $\mathrm{C}$ & $\mathrm{C}$ & $\mathrm{C}$ & $\begin{array}{c}\text { RI } \\
\text { private }\end{array}$ & $\mathrm{U}$ & $\mathrm{U}$ & $\mathrm{U}$ & $\mathrm{U}$ & $\mathrm{U}$ & $\mathrm{U}$ & $\mathrm{U}$ & RI public & $\begin{array}{c}\text { RI } \\
\text { public }\end{array}$ & $\begin{array}{c}\mathrm{RI} \\
\text { public/U }\end{array}$ & Co & $\mathrm{C}$ & $\mathrm{U}$ & Co & $\mathrm{S}$ \\
\hline Project type & Ppt & $\mathrm{Ppt} / \mathrm{I}$ & Ppt & $\mathrm{R}$ & $\mathrm{R}$ & BS & BS & BS & $\begin{array}{l}\mathrm{R} / \\
\mathrm{BS}\end{array}$ & BS & $\begin{array}{l}\mathrm{BS} \\
\mathrm{R}\end{array}$ & $\begin{array}{l}\mathrm{BS} \\
/ \mathrm{R}\end{array}$ & R/Pproc & Pproc & $\mathrm{R} / \mathrm{BS}$ & I & Ppt & $\mathrm{Ppt} / \mathrm{R}$ & I & Ppt \\
\hline Degree of complementary resources searched & $\mathrm{H}$ & M & $\mathrm{H}$ & $\mathrm{M}$ & $\mathrm{H}$ & $\mathrm{M}$ & $\mathrm{L}$ & $\mathrm{H}$ & $\mathrm{M}$ & $\mathrm{H}$ & $\mathrm{H}$ & $\mathrm{H}$ & $\mathrm{M}$ & $\mathrm{H}$ & $\mathrm{H}$ & $\mathrm{L}$ & $\mathrm{H}$ & $\mathrm{M}$ & $\mathrm{L}$ & $\mathrm{H}$ \\
\hline Degree of similar resources searched & $\mathrm{L}$ & $\mathrm{M}$ & $\mathrm{L}$ & $\mathrm{L}$ & $\mathrm{M}$ & $\mathrm{M}$ & $\mathrm{H}$ & $\mathrm{L}$ & $\mathrm{H}$ & $\mathrm{L}$ & $\mathrm{L}$ & $\mathrm{M}$ & $\mathrm{M}$ & $\mathrm{M}$ & $\mathrm{L}$ & $\mathrm{H}$ & $\mathrm{L}$ & $\mathrm{M}$ & $\mathrm{H}$ & $\mathrm{L}$ \\
\hline Technology Familiarity of the company & $\mathrm{H}$ & $\mathrm{M}$ & $\mathrm{H}$ & $\mathrm{M}$ & $\mathrm{L}$ & $\mathrm{M}$ & $\mathrm{M}$ & $\mathrm{L}$ & $\mathrm{M}$ & $\mathrm{L}$ & $\mathrm{L}$ & $\mathrm{L}$ & $\mathrm{M}$ & $\mathrm{M}$ & $\mathrm{M}$ & $\mathrm{H}$ & $\mathrm{M}$ & $\mathrm{M}$ & $\mathrm{H}$ & $\mathrm{M}$ \\
\hline Technology Familiarity of the Partner & $\mathrm{M}$ & $\mathrm{H}$ & $\mathrm{M}$ & $\mathrm{H}$ & $\mathrm{H}$ & $\mathrm{H}$ & $\mathrm{M}$ & $\mathrm{H}$ & $\mathrm{H}$ & $\mathrm{H}$ & $\mathrm{H}$ & $\mathrm{H}$ & $\mathrm{H}$ & $\mathrm{H}$ & $\mathrm{H}$ & $\mathrm{H}$ & $\mathrm{M}$ & $\mathrm{H}$ & $\mathrm{M}$ & $\mathrm{H}$ \\
\hline Market Familiarity of the company & $\mathrm{L}$ & $\mathrm{M}$ & $\mathrm{L}$ & $\mathrm{L}$ & $\mathrm{H}$ & $\mathrm{L}$ & $\mathrm{M}$ & $\mathrm{H}$ & $\mathrm{M}$ & $\mathrm{L}$ & $\mathrm{L}$ & $\mathrm{M}$ & $\mathrm{M}$ & $\mathrm{H}$ & $\mathrm{L}$ & $\mathrm{M}$ & $\mathrm{L}$ & $\mathrm{H}$ & $\mathrm{M}$ & $\mathrm{H}$ \\
\hline Market Familiarity of the Partner & $\mathrm{H}$ & $\mathrm{H}$ & $\mathrm{H}$ & $\mathrm{H}$ & $\mathrm{L}$ & $\mathrm{L}$ & $\mathrm{L}$ & $\mathrm{L}$ & $\mathrm{L}$ & $\mathrm{L}$ & $\mathrm{L}$ & $\mathrm{L}$ & $\mathrm{H}$ & $\mathrm{M}$ & $\mathrm{L}$ & $\mathrm{H}$ & $\mathrm{H}$ & $\mathrm{L}$ & $\mathrm{M}$ & $\mathrm{M}$ \\
\hline Technological Complementarity & $\mathrm{M}$ & $\mathrm{M}$ & $\mathrm{M}$ & $\mathrm{M}$ & $\mathrm{M}$ & $\mathrm{M}$ & $\mathrm{L}$ & $\mathrm{H}$ & $\mathrm{M}$ & $\mathrm{H}$ & $\mathrm{H}$ & $\mathrm{H}$ & $\mathrm{M}$ & $\mathrm{M}$ & $\mathrm{M}$ & $\mathrm{L}$ & $\mathrm{L}$ & $\mathrm{M}$ & $\mathrm{L}$ & $\mathrm{M}$ \\
\hline Market Complementarity & $\mathrm{H}$ & $\mathrm{M}$ & $\mathrm{H}$ & $\mathrm{H}$ & $\mathrm{M}$ & $\mathrm{L}$ & $\mathrm{M}$ & $\mathrm{H}$ & $\mathrm{M}$ & $\mathrm{L}$ & $\mathrm{L}$ & $\mathrm{M}$ & $\mathrm{M}$ & $\mathrm{M}$ & $\mathrm{L}$ & $\mathrm{M}$ & $\mathrm{H}$ & $\mathrm{H}$ & $\mathrm{L}$ & $\mathrm{M}$ \\
\hline Overall Complementarity & MH & $\mathrm{M}$ & MH & MH & $M$ & ML & ML & $\mathrm{H}$ & M & $\mathrm{M}$ & $\mathrm{M}$ & MH & $\mathrm{M}$ & M & ML & $\mathrm{L}$ & $\mathrm{MH}$ & $\mathrm{MH}$ & $\mathrm{L}$ & M \\
\hline Level of resources & $\mathrm{H}$ & $\mathrm{L}$ & $\mathrm{M}$ & $\mathrm{M}$ & $\mathrm{M}$ & $\mathrm{L}$ & $\mathrm{L}$ & $\mathrm{L}$ & $\mathrm{M}$ & $\mathrm{L}$ & $\mathrm{L}$ & $\mathrm{H}$ & $\mathrm{M}$ & $\mathrm{H}$ & $\mathrm{M}$ & $\mathrm{H}$ & $\mathrm{H}$ & $\mathrm{M}$ & $\mathrm{M}$ & $\mathrm{L}$ \\
\hline Technological risk & $\mathrm{M}$ & $\mathrm{M}$ & $\mathrm{M}$ & $\mathrm{H}$ & $\mathrm{H}$ & $\mathrm{H}$ & $\mathrm{M}$ & $\mathrm{H}$ & $\mathrm{H}$ & $\mathrm{H}$ & $\mathrm{M}$ & $\mathrm{M}$ & $\mathrm{M}$ & $\mathrm{M}$ & $\mathrm{H}$ & $\mathrm{L}$ & $\mathrm{M}$ & $\mathrm{L}$ & $\mathrm{L}$ & $\mathrm{L}$ \\
\hline Market risk & $\mathrm{L}$ & $\mathrm{L}$ & $\mathrm{L}$ & $\mathrm{H}$ & $\mathrm{L}$ & $\mathrm{L}$ & $\mathrm{L}$ & $\mathrm{H}$ & $\mathrm{L}$ & $\mathrm{H}$ & $\mathrm{H}$ & $\mathrm{M}$ & $\mathrm{L}$ & $\mathrm{M}$ & $\mathrm{M}$ & $\mathrm{M}$ & $\mathrm{H}$ & $\mathrm{M}$ & $\mathrm{L}$ & $\mathrm{L}$ \\
\hline Financial risk & $\mathrm{M}$ & $\mathrm{L}$ & $\mathrm{M}$ & $\mathrm{M}$ & $\mathrm{M}$ & $\mathrm{M}$ & $\mathrm{L}$ & $\mathrm{L}$ & $\mathrm{M}$ & $\mathrm{L}$ & $\mathrm{L}$ & $\mathrm{M}$ & $\mathrm{L}$ & $\mathrm{H}$ & $\mathrm{M}$ & $\mathrm{H}$ & $\mathrm{L}$ & $\mathrm{L}$ & $\mathrm{H}$ & $\mathrm{L}$ \\
\hline Competitive risk & $\mathrm{L}$ & $\mathrm{L}$ & $\mathrm{L}$ & $\mathrm{L}$ & $\mathrm{L}$ & $\mathrm{L}$ & $\mathrm{L}$ & $\mathrm{L}$ & $\mathrm{L}$ & $\mathrm{L}$ & $\mathrm{L}$ & $\mathrm{L}$ & $\mathrm{L}$ & $\mathrm{L}$ & $\mathrm{L}$ & $\mathrm{M}$ & $\mathrm{L}$ & $\mathrm{L}$ & $\mathrm{L}$ & $\mathrm{L}$ \\
\hline Overall project risk & ML & $\mathrm{L}$ & ML & MH & ML & ML & $\mathrm{L}$ & $\mathrm{M}$ & ML & $\mathrm{M}$ & ML & $\mathrm{M}$ & $\mathrm{L}$ & $\mathrm{M}$ & $\mathrm{M}$ & $\mathrm{M}$ & $\mathrm{MH}$ & $\mathrm{L}$ & ML & $\mathrm{L}$ \\
\hline Project duration & $\mathrm{M}$ & $\mathrm{M}$ & $\mathrm{M}$ & $\mathrm{M}$ & $\mathrm{H}$ & $\mathrm{H}$ & MH & $\mathrm{H}$ & $\mathrm{H}$ & $\mathrm{H}$ & $\mathrm{H}$ & $\mathrm{M}$ & MH & $\mathrm{M}$ & $\mathrm{H}$ & $\mathrm{M}$ & $\mathrm{M}$ & $\mathrm{L}$ & $\mathrm{M}$ & $\mathrm{L}$ \\
\hline Previous partner experience in alliances & $\mathrm{H}$ & $\mathrm{M}$ & $\mathrm{H}$ & $\mathrm{L}$ & $\mathrm{H}$ & $\mathrm{H}$ & $\mathrm{H}$ & $\mathrm{H}$ & $\mathrm{M}$ & $\mathrm{H}$ & $\mathrm{H}$ & $\mathrm{H}$ & $\mathrm{H}$ & $\mathrm{H}$ & $\mathrm{M}$ & $\mathrm{H}$ & $\mathrm{H}$ & $\mathrm{H}$ & $\mathrm{L}$ & $\mathrm{H}$ \\
\hline $\begin{array}{l}\text { Previous company experience in alliances with } \\
\text { that partner }\end{array}$ & $\mathrm{L}$ & $\mathrm{H}$ & $\mathrm{L}$ & $\mathrm{L}$ & M & M & $\mathrm{H}$ & $\mathrm{L}$ & M & $\mathrm{M}$ & $\mathrm{H}$ & $\mathrm{L}$ & $\mathrm{H}$ & $\mathrm{H}$ & M & $\mathrm{L}$ & $\mathrm{L}$ & $\mathrm{H}$ & $\mathrm{H}$ & $\mathrm{H}$ \\
\hline $\begin{array}{l}\text { Trust in your partner regarding contract } \\
\text { attendance and confidentiality }\end{array}$ & $\mathrm{H}$ & $\mathrm{H}$ & M & M & M & $\mathrm{L}$ & $\mathrm{H}$ & M & $\mathrm{H}$ & $\mathrm{H}$ & $\mathrm{H}$ & $\mathrm{H}$ & $\mathrm{H}$ & $\mathrm{H}$ & $\mathrm{H}$ & M & $\mathrm{H}$ & $\mathrm{H}$ & $\mathrm{M}$ & $\mathrm{H}$ \\
\hline $\begin{array}{l}\text { Trust in your partner regarding the attendance to } \\
\text { project terms and flexibility to adjusts }\end{array}$ & $\mathrm{H}$ & $\mathrm{H}$ & M & $\mathrm{H}$ & $\mathrm{H}$ & $\mathrm{L}$ & M & $\mathrm{M}$ & $\mathrm{L}$ & $\mathrm{H}$ & $\mathrm{H}$ & M & $\mathrm{H}$ & $\mathrm{H}$ & M & $\mathrm{M}$ & $\mathrm{H}$ & $\mathrm{H}$ & $\mathrm{M}$ & $\mathrm{H}$ \\
\hline $\begin{array}{l}\text { Trust in your partner regarding its own } \\
\text { competencies }\end{array}$ & $\mathrm{H}$ & $\mathrm{H}$ & $\mathrm{H}$ & $\mathrm{H}$ & $\mathrm{H}$ & $\mathrm{H}$ & $\mathrm{H}$ & $\mathrm{H}$ & $\mathrm{H}$ & $\mathrm{H}$ & $\mathrm{H}$ & $\mathrm{H}$ & $\mathrm{H}$ & $\mathrm{H}$ & $\mathrm{H}$ & $\mathrm{H}$ & $\mathrm{H}$ & $\mathrm{H}$ & $\mathrm{M}$ & $\mathrm{H}$ \\
\hline $\begin{array}{l}\text { Trust in your partner regarding existence of } \\
\text { management process that contribute to interaction } \\
\text { and integration }\end{array}$ & $\mathrm{H}$ & $\mathrm{M}$ & $\mathrm{M}$ & $\mathrm{L}$ & $\mathrm{H}$ & $\mathrm{L}$ & $\mathrm{M}$ & $\mathrm{M}$ & $\mathrm{H}$ & $\mathrm{H}$ & $\mathrm{H}$ & $\mathrm{H}$ & $\mathrm{H}$ & $\mathrm{H}$ & $\mathrm{H}$ & $\mathrm{M}$ & $\mathrm{H}$ & $\mathrm{H}$ & $\mathrm{L}$ & $\mathrm{H}$ \\
\hline Overall trust in the partner & $\mathrm{H}$ & $\mathrm{H}$ & $\mathrm{M}$ & MH & $\mathrm{H}$ & ML & MH & $\mathrm{M}$ & $\mathrm{MH}$ & $\mathrm{H}$ & $\mathrm{H}$ & $\mathrm{H}$ & $\mathrm{H}$ & $\mathrm{H}$ & $\mathrm{MH}$ & $\mathrm{M}$ & $\mathrm{H}$ & $\mathrm{H}$ & $\mathrm{M}$ & $\mathrm{H}$ \\
\hline
\end{tabular}

Revista de Administração e Inovação, São Paulo, v. 11, n.2, p. 241-272, abr./jun. 2014 
RAI - Revista de Administração e Inovação

ISSN: $1809-2039$

DOI: $10.5773 /$ rai.v11i2.1292

Organização: Comitê Científico Interinstitucional

Editor Científico: Milton de Abreu Campanario

Avaliação: Double Blind Review pelo SEER/OJS

Revisão: Gramatical, normativa e de Formatação

\section{Table 2: Alliances' episodes (cont.)}

\begin{tabular}{|c|c|c|c|c|c|c|c|c|c|c|c|c|c|c|c|c|c|c|c|c|}
\hline & \multicolumn{20}{|c|}{ Episodes number } \\
\hline Variables & 1 & 2 & 3 & 4 & 5 & 6 & 7 & 8 & 9 & 10 & 11 & 12 & 13 & 14 & 15 & 16 & 17 & 18 & 19 & 20 \\
\hline $\begin{array}{l}\text { Partner convergent expectations for continuity } \\
\text { of the project }\end{array}$ & $\mathrm{H}$ & $\mathrm{H}$ & $\mathrm{H}$ & $\mathrm{L}$ & $\mathrm{H}$ & $\mathrm{H}$ & $\mathrm{H}$ & M & $\mathrm{H}$ & $\mathrm{H}$ & $\mathrm{H}$ & $\mathrm{H}$ & $\mathrm{H}$ & $\mathrm{H}$ & $\mathrm{M}$ & $\mathrm{H}$ & $\mathrm{H}$ & $\mathrm{H}$ & $\mathrm{H}$ & $\mathrm{H}$ \\
\hline Strategic objectives expectations level & $\mathrm{H}$ & $\mathrm{H}$ & $\mathrm{H}$ & $\mathrm{H}$ & $\mathrm{H}$ & $\mathrm{H}$ & $\mathrm{H}$ & $\mathrm{H}$ & $\mathrm{H}$ & $\mathrm{M}$ & $\mathrm{M}$ & $\mathrm{H}$ & $\mathrm{H}$ & $\mathrm{H}$ & $\mathrm{H}$ & $\mathrm{H}$ & $\mathrm{H}$ & $\mathrm{M}$ & $\mathrm{H}$ & $\mathrm{M}$ \\
\hline Sharing of financial investments expectations & $\mathrm{H}$ & $\mathrm{H}$ & $\mathrm{H}$ & $\mathrm{M}$ & $\mathrm{M}$ & $\mathrm{L}$ & $\mathrm{M}$ & $\mathrm{L}$ & $\mathrm{H}$ & $\mathrm{M}$ & $\mathrm{L}$ & $\mathrm{H}$ & $\mathrm{M}$ & $\mathrm{H}$ & $\mathrm{H}$ & $\mathrm{H}$ & $\mathrm{H}$ & $\mathrm{M}$ & $\mathrm{L}$ & $\mathrm{M}$ \\
\hline Sharing of R\&D competences expectations & $\mathrm{H}$ & $\mathrm{H}$ & $\mathrm{H}$ & $\mathrm{H}$ & $\mathrm{H}$ & $\mathrm{H}$ & $\mathrm{H}$ & $\mathrm{H}$ & $\mathrm{H}$ & $\mathrm{M}$ & $\mathrm{M}$ & $\mathrm{H}$ & $\mathrm{H}$ & $\mathrm{H}$ & $\mathrm{H}$ & $\mathrm{M}$ & $\mathrm{H}$ & $\mathrm{H}$ & $\mathrm{H}$ & $\mathrm{H}$ \\
\hline Sharing of Market competences expectations & $\mathrm{H}$ & $\mathrm{H}$ & $\mathrm{H}$ & $\mathrm{H}$ & $\mathrm{L}$ & $\mathrm{L}$ & $\mathrm{M}$ & $\mathrm{L}$ & $\mathrm{H}$ & $\mathrm{L}$ & $\mathrm{L}$ & $\mathrm{M}$ & $\mathrm{H}$ & $\mathrm{H}$ & $\mathrm{H}$ & $\mathrm{H}$ & $\mathrm{H}$ & $\mathrm{M}$ & $\mathrm{H}$ & $\mathrm{H}$ \\
\hline Partner geographic category & IN & $\mathrm{N}$ & IN & $\mathrm{N}$ & $\mathrm{N}$ & $\mathrm{N}$ & $\mathrm{N}$ & $\mathrm{N}$ & $\mathrm{N}$ & $\mathrm{N}$ & $\mathrm{N}$ & IN & $\mathrm{N}$ & $\mathrm{N}$ & $\mathrm{N}$ & IN & IN & $\mathrm{N}$ & IN & IN \\
\hline Access to new raw materials sources & $\mathrm{L}$ & $\mathrm{L}$ & na & na & na & na & na & na & na & na & na & na & na & na & na & $\mathrm{H}$ & na & na & $\mathrm{H}$ & na \\
\hline
\end{tabular}

\section{Legend:}

H: high; MH: medium-high; M: medium: ML: medium-low and L: low

na: not applicable

BS: basic science; R: radical innovation; Ppt: platform of products; Pproc: platform of processes; I: incremental.

C: customer; Co: competitor; S: supplier; U: university; RI: research institute; priv: private. N: national; IN: international. 